\title{
Primary splenic diffuse large B-cell lymphoma manifesting in red pulp
}

\author{
Makoto Kashimura • Masahiro Noro • \\ Bunshiro Akikusa $\cdot$ Atsushi Okuhara $\cdot$ Shuji Momose • \\ Ikuo Miura • Masaru Kojima $\cdot$ Jun-ichi Tamaru
}

Received: 9 April 2008 /Revised: 4 September 2008 / Accepted: 5 September 2008 / Published online: 26 September 2008

(C) The Author(s) 2008. This article is published with open access at Springerlink.com

\begin{abstract}
We evaluated six cases of diffuse large B-cell lymphoma (DLBCL) involving the red pulp of the spleen. All had B symptoms and an aggressive clinical course. The lymphoma cells proliferated diffusely and non-cohesively in the cords of the red pulp. The lymphoma involved the bone marrow in four of the five patients and the liver in all four of the patients examined. However, lymph node (LN) involvement was rare at presentation, and systemic LN involvement was not observed even in the terminal phase. The lymphoma cells infiltrated the intrasinusoidal/intravascular and interstitial spaces of the involved tissues and were
\end{abstract}

\section{Kashimura $(\bowtie)$}

Department of Hematology, Matsudo City Hospital, 4005 Kamihongo Matsudo,

Chiba 271-8511, Japan

e-mail: kasimura@mvi.biglobe.ne.jp

M. Noro $\cdot$ B. Akikusa

Department of Pathology, Matsudo City Hospital,

Matsudo, Japan

\author{
A. Okuhara \\ Laboratory of Hematology, Matsudo City Hospital, \\ Matsudo, Japan \\ S. Momose $\cdot$ J.-i. Tamaru \\ Department of Pathology, Saitama Medical Center, \\ Saitama Medical University, \\ Kawagoe, Japan \\ I. Miura \\ Department of Hematology and Oncology, \\ St Marianna University School of Medicine, \\ Kawasaki, Japan

\section{Kojima} \\ Department of Pathology and Clinical Laboratories, \\ Gunma Cancer Center Hospital, \\ Ohta, Japan
}

detected in the peripheral blood in two of the six patients. CD5-expressing lymphoma cells were detected in four of the five patients examined. Because these cases had some unique clinical features and occurred in distinct splenic sites, we proposed that primary splenic DLBCL manifesting in red pulp is a distinct clinicopathological entity.

Keywords Large B-cell lymphoma · Splenic red pulp . Intrasinusoidal lymphomatous infiltration · Bone marrow . Liver

\section{Introduction}

Extranodal diffuse large B-cell lymphomas (DLBCLs) have specific clinicopathologic features that are dependent on the organ of origin [1]. Primary splenic DLBCL is a rare type of lymphoma. The majority of the DLBCLs are derived from the white pulp of the spleen and form one large, or multiple nodules [2]. Before the advent of immunohistological examination, the absence of mass formation and the diffuse infiltration of large neoplastic cells into the red pulp might have been diagnosed as malignant histiocytosis [3]. Kuratsune et al. [4] reported the first case of DLBCL that non-cohesively proliferated into the splenic red pulp and demonstrated clinicopathological features of malignant histiocytosis. Since their initial report, only 18 cases of DLBCLs non-cohesively infiltrating the splenic red pulp have been reported [4-13]. These reports support the existence of DLBCL manifesting in the splenic red pulp (DLBCLRP). Kroft et al. [8] identified two cases of DLBCLRP involving the bone marrow (BM) and the liver, and Morice et al. [10] reported two cases of DLBCLRP with prominent $\mathrm{BM}$ intravascular/intrasinusoidal lymphomatous infiltration. 
Because there have been few case reports of DLBCLRP, there is no comprehensive list of its clinicopathological features. To clarify the features of this rare lymphoma, we describe six new cases of DLBCLRP and present an analysis of the clinicopathological features of an additional 18 previously reported cases [4-13]. After reviewing the data, we developed seven characteristic features of DLBCLRP. Based on these features, we propose that DLBCLRP is a distinct clinicopathologic entity. Moreover, we discuss the relationship between DLBCLRP and an Asian variant of intravascular lymphomatosis (IVL) with splenomegaly [14].

\section{Materials and methods}

Retrospective analyses were conducted for six patients clinicopathologically diagnosed with primary splenic large B-cell lymphoma manifesting in red pulp in our hospital from 2000 to 2007 . Two hundred and ninety two patients were diagnosed with malignant lymphoma, including 228 with B-cell lymphomas (DLBCL 129, follicular lymphoma 58 , marginal zone lymphoma 19 , mantle cell lymphoma 6 , etc), 45 with T-cell lymphomas, and 12 with Hodgkin's lymphomas during this 8 -year period. Thirteen patients were diagnosed with primary splenic lymphoma, two with splenic marginal zone lymphoma, one with follicular lymphoma, and ten with DLBCL. Two patients were diagnosed as having DLBCL with a micronodular pattern. Eight patients were clinically diagnosed with DLBCLRP; however, two were excluded based on the unavailability of splenic tissues. All procedures were performed with informed consent of the patients.

Tissue specimens obtained from surgery, biopsy, or necropsy were fixed in formalin and embedded in paraffin. The paraffin-embedded sections were dewaxed with xylene. The sections were stained with hematoxylin-eosin (HE) for light microscopic examination, and by the streptavidinbiotin-peroxidase method (Nichirei Co., Tokyo, Japan) for immunohistochemical analysis. The panel of primary antibodies included L26 (CD20), JCB117 (CD79a), F7.2.38 (CD3), UCHL-1 (CD45RO), 1F8 (CD21), 124 (Bcl-2), PGB6p (Bcl-6), MIB-1 (Ki-67), MUM1p (MUM1), IgM polyclonal (DAKO A/S, Glostrup, Denmark), MT1 (CD43), 4C7 (CD5), 56C6 (CD10), 1B12 (CD23), 1G12 (CD30), IgD polyclonal (Novocastra, Newcastle upon Tyne, UK), and SP4 (Cyclin D1, Lab Vision, Fremont, CA, USA). The primary antibodies were replaced with mouse or rabbit serum as a negative control.

Epstein-Barr virus (EBV)-encoded RNA (EBER) was detected by in situ hybridization (ISH). ISH was performed using the BioGenex Automated Staining System (i6000; BioGenex; San Ramon, CA, USA). The paraffin-embedded sections were dewaxed with xylene, treated with proteinase $\mathrm{K}$, and hybridized with a fluorescein-conjugated oligonucleotide EBER probe (PR005-10X, BioGenex). To visualize the bound probe, a Super Sensitive polymer-HRP ISH Detection System (DF300-YCX, BioGenex) was used according to the manufacturer's instructions.

Karyotypes were obtained at the time of diagnosis from all six patients from spleen $(n=5)$, and lymph node (LN; $n=1)$ samples, as previously described [15]. Chromosomal abnormalities were described according to ISCN [16].

Serum samples were analyzed with an immunofluorescence kit using anti-EBV capsid antigen (VCA), early antigen, and EBV-encoded nuclear antigen (TFB Inc., Tokyo, Japan). Antibodies against the human immunodeficiency virus (HIV) and HTLV-1 were examined using chemiluminescent enzyme immunoassay kits (Abbot Japan and Fuji Rebio Inc., Tokyo, Japan).

We characterized the degree of extramedullary hematopoiesis in the splenic samples as erythropoietic (grade 1), granulopoietic (grade 2), and trilineage hematopoietic (grade 3). Hemophagocytosis of normal splenic histiocytes was characterized as grade $1(<10)$ and grade $2(>10)$ erythrophagocytes in 10 high power fields. In bone marrow samples, grade 1 indicated thrombophagocytosis and grade 2 indicated leukoerythrophagocytosis.

\section{Results}

\section{Clinical features}

In this series, five of the six patients were men (age, 6481 years; median, 69 years). At presentation, all patients were febrile. Four patients (nos. 1, 3-5) had splenomegaly without lymphadenopathy. One patient (no. 2) had localized LN swelling at presentation and a second patient (no. 6) had localized LN swelling at the time of surgery, which suggested the presence of a primary splenic lymphoma. All patients had high levels of lactate dehydrogenase $(\mathrm{LDH})$, soluble interleukin-2 receptor, hypoalbuminemia, and moderately elevated C-reactive protein (Table 1). Differential blood counts revealed the following: Marked lymphocytopenia was detected in all patients except 1 (no. 5), thrombocytopenia was detected in five patients (nos. 1-5), and anemia was detected in four patients (nos. 2, 4-6). In two patients (nos. 1 and 4), lymphoma cells were detected in the peripheral blood (Table 2). Cholestasis and hepatocellular damage with hepatomegaly was observed in four patients (nos. 1, 2, 5, and 6), suggesting hepatic involvement.

Characteristic clinical features of DLBCLRP (Table 2) included BM involvement in four of the five patients (nos. $1,2,5$, and 6; determined at admission), and hepatic 
Table 1 Laboratory data, clinical stage, and international prognostic index upon admission

\begin{tabular}{|c|c|c|c|c|c|c|}
\hline & Patient 1 & Patient 2 & Patient 3 & Patient 4 & Patient 5 & Patient 6 \\
\hline Age (years)/sex & $75 \mathrm{M}$ & $68 \mathrm{M}$ & $70 \mathrm{M}$ & $81 \mathrm{M}$ & $64 \mathrm{~F}$ & $65 \mathrm{M}$ \\
\hline White blood cell count, $\times 10^{9} / \mathrm{L}$ & 2.4 & 3.9 & 7.6 & 7.4 & 2.3 & 2.9 \\
\hline Neutrophils, $\times 0^{9} / \mathrm{L}$ & 1.8 & 3.3 & 6.6 & 4.4 & 0.9 & 2.2 \\
\hline Lymphocytes, $\times 10^{9} / \mathrm{L}$ & 0.4 & 0.2 & 0.4 & 0.7 & 1.1 & 0.5 \\
\hline Hemoglobin level, g/L & 140 & 116 & 133 & 100 & 87 & 91 \\
\hline Platelet count, $\times 10^{9} / \mathrm{L}$ & 40 & 83 & 99 & 116 & 38 & 137 \\
\hline $\mathrm{LDH}$ & 1,045 & 4,312 & 1,822 & 2,690 & 460 & 404 \\
\hline ALP & 842 & 1,677 & 228 & 193 & 2,102 & 1,168 \\
\hline$\gamma$-GTP & 489 & 374 & 120 & 26 & 191 & 153 \\
\hline LAP & 131 & 225 & & 80 & 161 & 138 \\
\hline AST & 217 & 380 & 55 & 67 & 51 & 49 \\
\hline ALT & 34 & 211 & 37 & 11 & 36 & 58 \\
\hline CRP & 165 & 122 & 105 & 93 & 58 & 25 \\
\hline $\mathrm{TP}$ & 56 & 53 & 65 & 56 & 60 & 49 \\
\hline Albumin & 27 & 26 & 30 & 29 & 28 & 25 \\
\hline sIL-2R & 4,050 & 5,060 & 5,250 & 7,790 & 19,500 & 15,800 \\
\hline Ferritin & 847 & na & 710 & na & 276 & 2,110 \\
\hline Hemophagocytosis in $\mathrm{BM}^{\mathrm{a}}$ & + & + & + & na & + & ++ \\
\hline Clinical stage & $4 \mathrm{~B}$ & $4 \mathrm{~B}$ & $4 \mathrm{~B}$ & $4 \mathrm{~B}$ & $4 \mathrm{~B}$ & $4 \mathrm{~B}$ \\
\hline IPI & $\mathrm{H}$ & $\mathrm{H}$ & $\mathrm{H}$ & $\mathrm{H}$ & $\mathrm{H}$ & $\mathrm{H}$ \\
\hline
\end{tabular}

Abbreviation and normal level (in parentheses): $M$ male, $F$ female, $A L P$ alkaline phosphatase (130-350 in cases 1, 4, 5, and 6; 66-220 in cases 2 and 3), $L D H$ lactate dehydrogenase (80-200 in cases 1, 4, 5, and 6; 255-434 in cases 2 and 3), LAP leucin aminopeptidase (M 11-64, F 8-45), $A S T$ aspirate aminotransferase (0-31), ALT alanine aminotransferase (0-41), CRP C-reactive protein (less $3 \mathrm{mg} / \mathrm{L}$ ), sIL-2R soluble interleukin-2 receptor (220-530 U/mL), TP total protein (67-83 g/L), albumin (38-53 g/L), ferritin (M 27-320, F 3.4-89 ng/mL), BM bone marrow, na not available, IPI international prognostic index, $H$ high risk

${ }^{a}$ Grading of hemophagocytosis of normal histiocytes in bone marrow as grade + and ++ indicating thrombophagocytosis and leukoerythrophagocytosis

infiltration in four patients (nos. 1, 5, and 6, and no. 2 determined at biopsy and necropsy, respectively). Enlarged LN were rare and limited to localized areas. Systemic lymphadenopathy was not observed even during the terminal stage of the disease. Hemophagocytosis by normal histiocytes was observed in the spleen and BM of all six patients.

We assessed two treatment groups: (a) three patients (nos. 2-4) were treated with six courses of CHOP (combination of doxorubicin, vincristine, cyclophosphamide, and prednisolone), and (b) the remaining three patients (nos. 1, 5, and 6) were treated with six courses of rituximab and CHOP followed by two courses of rituximab, etoposide, and nimustine hydrochloride with intrathecal administration of methotrexate, Ara-C, and prednisolone for prophylaxis of central nervous system lymphoma.

Follow-up (1-75 months; median, 38 months) information was obtained for all six patients. Two patients (nos. 4 and 2) of

Table 2 Clinicopathological features of cases with primary splenic LBC lymphoma diffusely infiltrating the red pulp

\begin{tabular}{|c|c|c|c|c|c|c|c|c|c|c|c|c|c|c|c|c|}
\hline & & & \multirow{2}{*}{$\begin{array}{l}\text { Spleen } \\
\text { Weight }\end{array}$} & \multicolumn{2}{|c|}{ Red pulp } & \multirow[t]{2}{*}{$\mathrm{HPC}^{\mathrm{a}}$} & \multirow[t]{2}{*}{$\mathrm{EMH}^{\mathrm{b}}$} & \multirow[t]{2}{*}{$\mathrm{BM}$} & \multirow[t]{2}{*}{ ISI } & \multirow[t]{2}{*}{ II } & \multirow[t]{2}{*}{ Liver } & \multirow[t]{2}{*}{ ISI } & \multirow[t]{2}{*}{ Portal } & \multicolumn{2}{|c|}{ Lymph node } & \multirow[t]{2}{*}{ Blood } \\
\hline & & & & Cord & Sinus & & & & & & & & & Splenic H & Syst & \\
\hline Patient 1 & 75 & M & 525 & + & + & ++ & +++ & + & + & + & + & + & + & - & - & $8 \%$ \\
\hline Patient 2 & 68 & M & na & $+^{\mathrm{c}}$ & $+^{\mathrm{c}}$ & + & + & + & - & + & $+^{\mathrm{c}}$ & $+^{\mathrm{c}}$ & $+^{\mathrm{c}}$ & na & Inguinal & - \\
\hline Patient 3 & 70 & M & 900 & + & + & ++ & + & - & - & - & na & na & na & + & - & - \\
\hline Patient 4 & 81 & M & 546 & + & + & + & + & nd & na & na & na & na & na & - & - & $16 \%$ \\
\hline Patient 5 & 64 & $\mathrm{~F}$ & 675 & + & + & + & +++ & + & - & + & + & + & + & + & - & - \\
\hline Patient 6 & 65 & M & 220 & + & + & + & + & + & - & + & + & + & + & - & Abdominal & - \\
\hline
\end{tabular}

ISI intrasinusoidal infiltration, II interstitial infiltration, HPC hemophagocytosis, EMH extramedullary hematopoiesis

${ }^{a}$ Grading of hemophagocytosis of normal histiocytes in spleens as + and ++ indicating less than ten and more than ten erythrophagocytes in 10 high power fields

${ }^{\mathrm{b}}$ Grading of extramedullary hematopoiesis in spleens as,+++ , and +++ indicating erythropoiesis, granulopoiesis, and trilineage hematopoiesis, respectively

${ }^{\mathrm{c}}$ Necropsy 
the former group died of lymphoma, within 1 and 5 months of the onset of the disease, respectively. All three patients of the latter group survived following first complete remission.

All patients were negative for HIV and HTLV-1. Antibodies to EBV indicated an old infection. M-protein and autoantibodies, including Coombs' test, were not detected in any of the patients.

\section{Pathologic features}

Spleen size and weight were abnormally high in all informative cases (nos. 1, 3, 4, 5, and 6). In one patient (no. 2), spleen weight was not available (Table 2). The weight of the spleen, which is 80 to $120 \mathrm{~g}$ in healthy Japanese adults, was 220 to $900 \mathrm{~g}$ (median, $546 \mathrm{~g}$ ) in the patients. Cut surfaces of the spleens showed beef red color and a lack of mass formation. In all six patients, the splenic red pulp was expanded and diffusely infiltrated by noncohesive large lymphoma cells (nos. 1, 3, 4, 5, and 6 before therapy, and no. 2 at necropsy). Lymphoma cells were present in the cord and had infiltrated the sinuses to various degrees (Fig. 1a-c). In one patient (no. 5), a small number of large lymphoma cells were scattered among numerous $\mathrm{T}$ cells/histiocytes, and the patient was diagnosed with T-cell/ histiocyte-rich B-cell lymphoma. All patients had extramedullary hematopoiesis of erythroblasts. Trilineage extramedullary hematopoiesis was observed in two patients (nos. 1 and 5). In all six patients, there were an abnormally high number of histiocytes, which were engaged in hemophagocytosis. In two (nos. 1 and 3) of these patients, there was intensive hemophagocytosis.

In one patient (no. 1), CD20 and CD34 immunohistochemistry revealed large lymphoma cells that were visible in the sinusoids and a few were present in the cords (Fig. 2a,b). In the remaining patients, the lymphoma cells had diffusely infiltrated the interstitial spaces (Fig. 2e). It is possible that the intravascular lymphomatous infiltration of this lymphoma disappeared due to the destruction of endothelial cells by lymphoma cells in the significantly infiltrated lesions. Thrombophagocytosis in the BM was observed in all patients, and leukoerythrophagocytosis was detected in one of the five patients examined (no. 6).

In four patients examined (nos. 1, 5, and 6 at biopsy, and no. 2 at necropsy), lymphoma cells had infiltrated into the sinusoidal and portal areas of the liver (Fig. 2c).

In one patient (no. 2), the lymph nodes were replaced completely by lymphoma cells. Intravascular infiltration of lymphoma cells was not visible in the HE-stained samples. However, diffuse infiltration into the vascular spaces was clearly detected by immunostaining for CD34 (Fig. 2d). Furthermore, in one patient (no. 4), intravascular infiltration of lymphoma cells was prominent in the adipose tissue of the splenic hilus (Fig. 2f), and in another patient (no. 1) infiltration into the subcutaneous vessels was observed. In three patients (nos. 2-4), lymphoma cells had infiltrated below the endothelial cells or into the vascular wall (Fig. 1d).

Immunohistochemistry of lymphoma cells

All patients had lymphoma cells positive for CD20 and Bcl-2 and negative for EBER, Cyclin D1, and CD23 (Table 3). The cells in two patients (nos. 3 and 6) were positive for CD10. Of the remaining four patients with CD10-negative lymphoma cells, the cells were negative for bcl-6 in three patients (nos.1, 4, and 5), and positive for bcl6 and MUM1 in one patient (no. 2). CD5-positive cells were found in four of five patients by flow cytometry and three of five patients by immunohistochemistry. Cells of five patients examined were positive for surface membrane (sm) IgM and negative for smIgD (Table 3). Positive rate of Ki67 varied from $10 \%$ to $80 \%$.

\section{Chromosomal analysis}

Chromosomes were analyzed in all six patients. Two patients (nos. 5 and 6) had normal karyotypes. The remaining four patients (nos. 1-4) were CD5-positive and carried complex chromosomal aberrations. One of these patients (no. 4) showed the 11q13 aberrations, whereas another (no. 2) showed the 3q27 abnormality (Table 4).

\section{Discussion}

Here, we have reported six cases of DLBCLRP. To further clarify the clinicopathological characteristics of DLBCLRP, we analyzed a total of 24 cases (Tables 5 and 6) of DLBCLRP, including six cases encountered by one of the authors (M. Kashimura). In the present series, 18 of the 24 patients were men and the age range of all the patients was 40-81 years (median, 64.5 years).

The size and weight of the spleens that were examined had increased in all informative cases. Spleen weight data were not available for five of the 24 patients. The weight of the spleen, which is $80-120 \mathrm{~g}$ and $110-170 \mathrm{~g}$ in healthy adults of Japan and western countries, respectively, was 220 to $2,600 \mathrm{~g}$ (median, 1,300 g) in the present cases.

We found that DLBCLRP has seven characteristic clinicopathological features as shown in Table 7 and a pattern of infiltration of the spleen. Lymphoma cells were present in the cord in all but one case of the 24 cases of splenic infiltration. In the remaining patient, the lymphoma cells were restricted to the sinusoids [7]. 


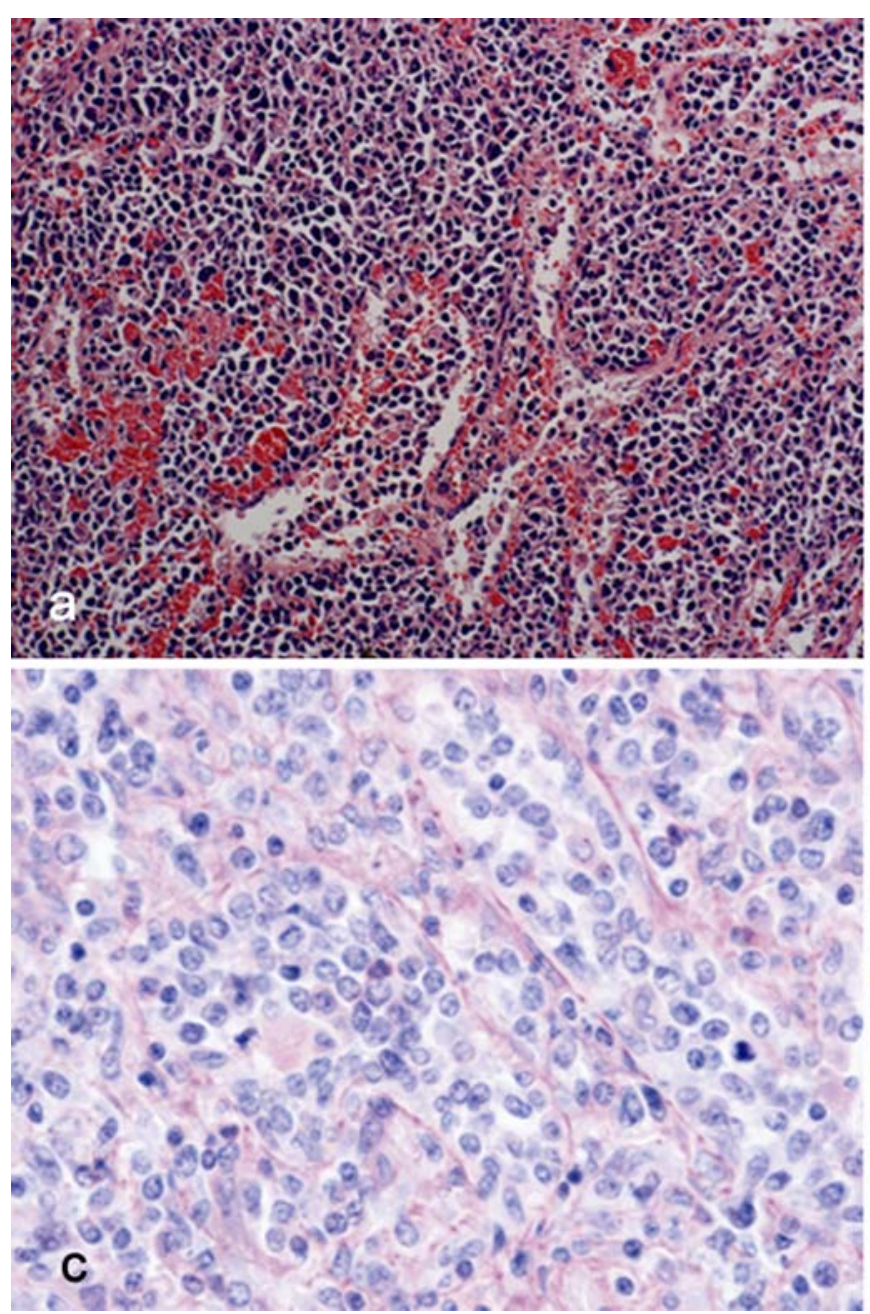

Fig. 1 Lymphoma cells infiltrate the Billroth's cords and sinuses of the splenic red pulp and the vascular wall. a Medium power field of the affected spleen. The tumor cells have diffusely infiltrated the Billroth's cords of red pulp, case 3 HE staining. Original magnification, $\times 100$. b Medium power field of the affected spleen. Tumor cells have diffusely infiltrated the Billroth's cords as well as the sinusoid, case $4 \mathrm{HE}$ staining. Original magnification, $\times 100$. c High power

At presentation, lymphoma cells were frequently found in the $\mathrm{BM}(13 / 20,65 \%)$ and the liver $(11 / 17,65 \%)$. However, LN involvement was rare and limited to a localized area $(10 / 21,48 \%)$, and $\mathrm{LN}$ swelling was not significant. Systemic LN swelling was not observed, even during the terminal phase of the disease.

Another characteristic of DLBCLRP is an intrasinusoidal infiltration of lymphoma cells in the BM $(3 / 7,43 \%)$ and the liver $(8 / 8,100 \%)$ as well as interstitial infiltration of lymphoma cells in the BM $(10 / 11,91 \%)$ and the liver $(7 / 8$, $88 \%$ ). Furthermore, we observed intravascular infiltration of lymphoma cells in the LN (no. 2) and the adipose tissue (nos. 1 and 4), and the presence of lymphoma cells in the peripheral blood $(10 / 23,43 \%)$. This rate appears higher than that observed for nodal DLBCL.

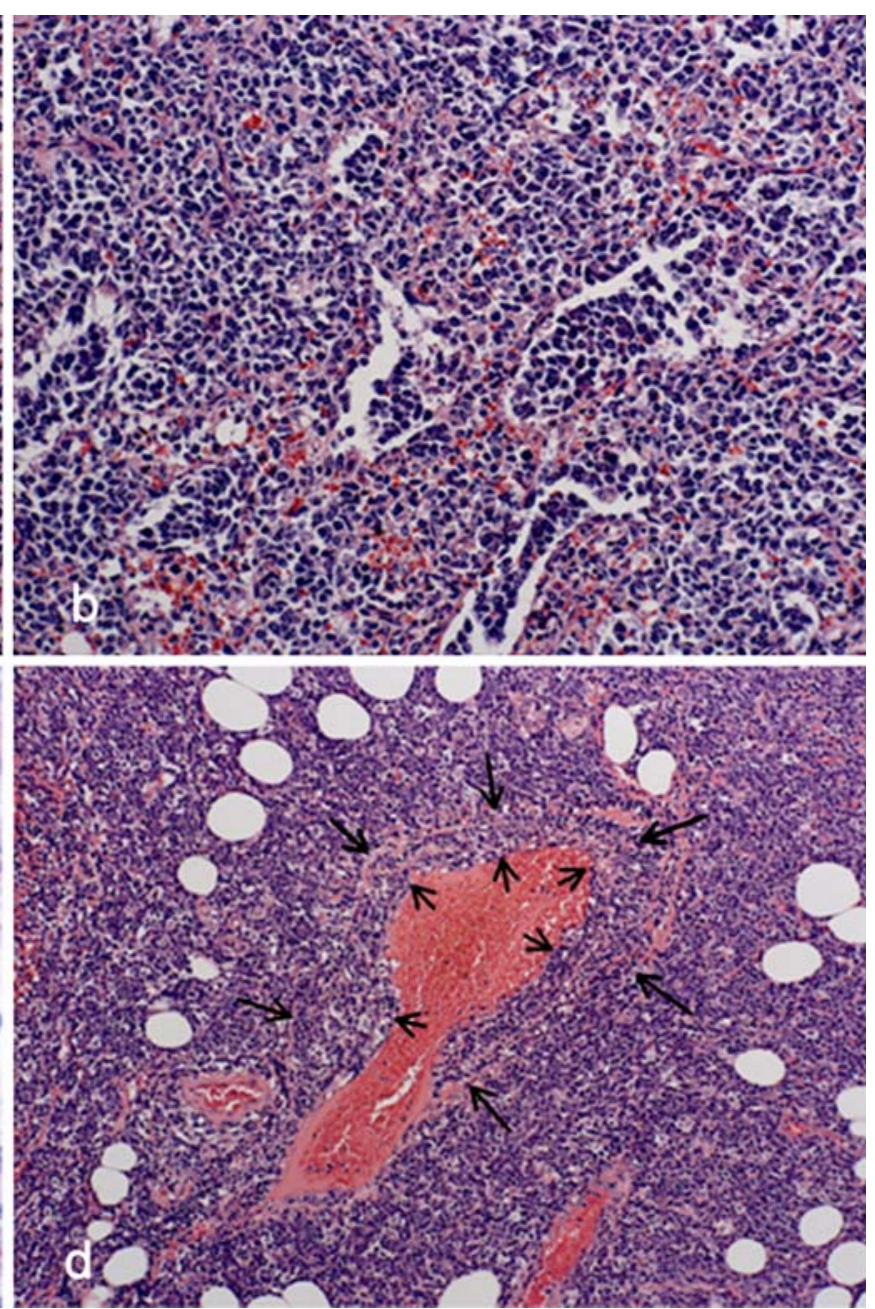

magnification of PAS-stained sections showing the basement membrane of the sinusoid. Note the intrasinusoidal and extrasinusoidal lymphoma cell infiltrations, case 1 . Original magnification, $\times 350$. d Monomorphous lymphoma cell infiltration in the vascular wall. Short arrows indicate the vascular endothelial cells and long arrows indicate the arterial adventitia. Case $3 \mathrm{HE}$ staining. Original magnification, $\times 40$

Moreover, we observed lymphoma cell surface expression of the CD5 antigen in eight of the ten patients (80\%) $[8,10,12]$, including four of our original six patients. Low intensity of the lymphoma cell CD5 antigen might not be detectable by immunohistochemistry (Tables 3 and 6).

None of the patients had a history of chronic lymphocytic leukemia. Transformation of splenic marginal zone lymphoma (SMZL) into DLBCL [17, 18], which might be associated with CD5-positive transformation, must be ruled out in order to diagnose DLBCLRP as the de novo DLBCL. Despite a careful study, we were unable to find proliferative lesions of medium-sized lymphoma cells in any of our cases, which is usually observed when DLBCL transforms from SMZL. Lymphoma cells of all five patients examined were positive for smIgM; however, they were 

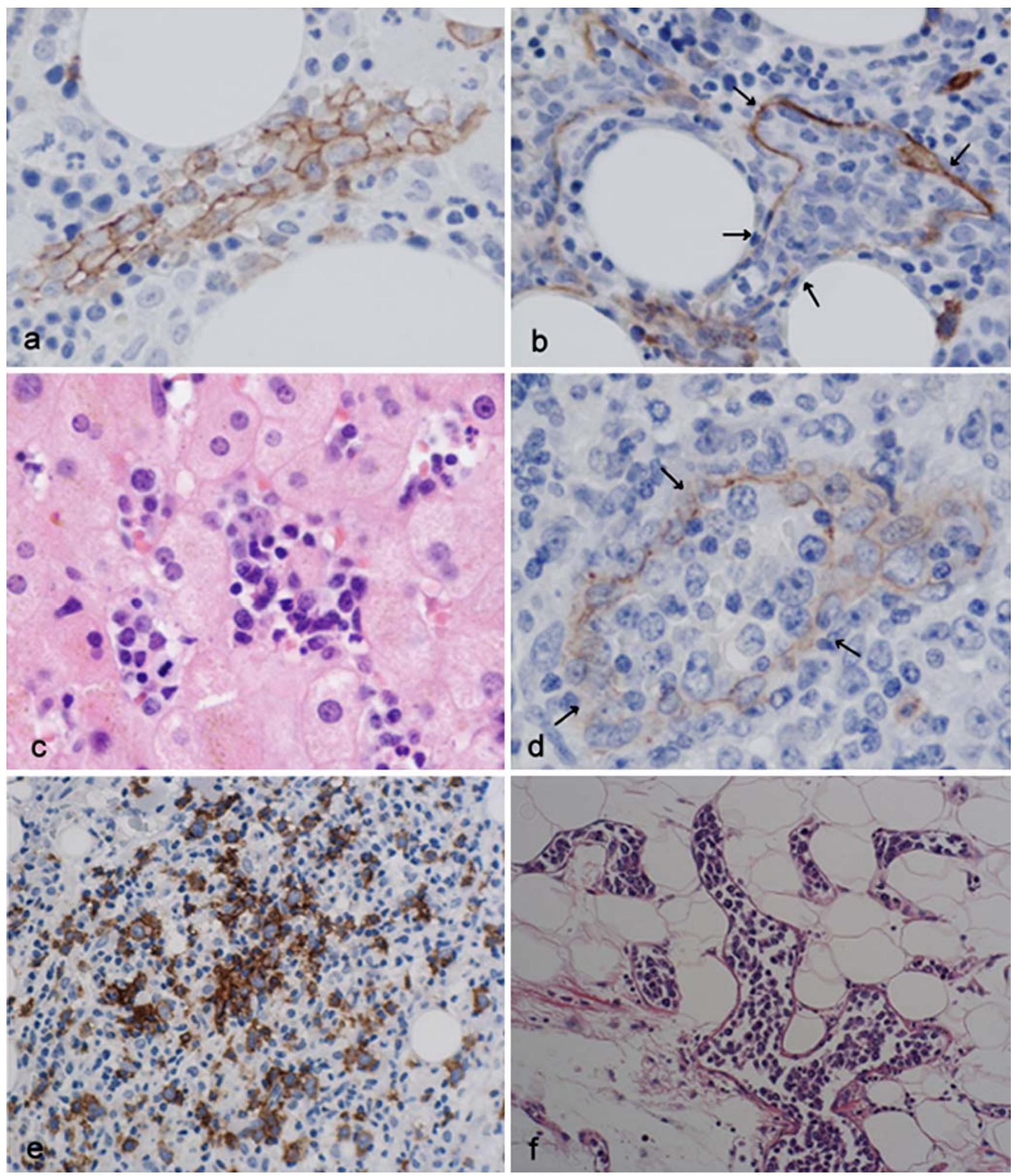

Fig. 2 Intrasinusoidal/intravascular lymphoma cell infiltration in the bone marrow, liver, lymph node, and adipose tissue. a CD20 immunostaining showing the predominantly intrasinusoidal pattern of marrow infiltration by large B-cell lymphoma, case 1. Original magnification, $\times 450$. b CD34 immunoperoxidase staining of bone marrow sinusoidal cell lining (arrow). Large lymphoma cells are present in a sinus, case 1 . Original magnification, $\times 350$. $\mathbf{c}$ High power field of affected liver. Note an intrasinusoidal infiltration of large lymphoma cells, case $1 \mathrm{HE}$

staining. Original magnification, $\times 350$. d CD34 immunoperoxidase staining highlights the intravascular lymphoma cells from diffuse lymphomatous infiltration of lymph node parenchyma. Arrows show sinusoidal cell lining, case 2 . Original magnification, $\times 400$. e Medium power field of the affected BM. The tumor cells diffusely infiltrated in the cords of BM, case 6 . Original magnification, $\times 100$. f Perisplenic adipose tissue. Note the intravascular infiltrate of large lymphoma cells, case $4 \mathrm{HE}$ staining. Original magnification, $\times 150$ 
Table 3 Immunophenotype of primary splenic LBC lymphoma diffusely infiltrating the red pulp

\begin{tabular}{|c|c|c|c|c|c|c|c|c|c|c|c|c|c|c|}
\hline & $\mathrm{CD} 20$ & $\begin{array}{l}\text { CD5: } \\
\text { FCM }\end{array}$ & $\begin{array}{l}\text { CD5: } \\
\text { IHC }\end{array}$ & CD10 & $\begin{array}{l}\text { Cyclin } \\
\text { D1 }\end{array}$ & bcl-2 & $\mathrm{CD} 23$ & MUM1 & Ki67 (\%) & bcl-6 & $\begin{array}{l}\text { EBER- } \\
\text { ISH }\end{array}$ & $\begin{array}{l}\text { smIg } \\
\text { FCM }\end{array}$ & $\begin{array}{l}\text { IgM } \\
\text { IHC }\end{array}$ & $\begin{array}{l}\text { IgD } \\
\text { IHC }\end{array}$ \\
\hline Patient 1 & + & + & Weak+ & - & - & + & - & - & 20 & - & - & M-k & + & - \\
\hline Patient 2 & + & + & + & - & - & + & - & + & 20 & + & - & $\mathrm{K}$ & na & na \\
\hline Patient 3 & + & + & - & + & - & + & - & + & 30 & - & - & $\lambda$ & + & - \\
\hline Patient 4 & + & + & + & - & - & + & - & - & 10 & - & - & $M-\lambda$ & + & - \\
\hline Patient 5 & + & na & - & - & - & + & - & - & 80 & - & - & na & + & - \\
\hline Patient 6 & + & - & - & + & - & + & - & - & 20 & + & - & na & + & - \\
\hline
\end{tabular}

FCM flow cytometry, IHC immunohistochemistry, ISH in situ hybridization, smIg surface membrane immunoglobulin

negative for SmIgD, which is unusual for SMZL cells [19, 20]. Although four of the six patients (nos. 1-4) showed complex chromosomal aberrations, none of them had trisomy 3 or allelic loss of 7q21-32, which is usually observed with SMZL [21, 22]. Clinically, autoimmune phenomena and the presence of M-protein have been frequently observed in SMZL patients [17, 20, 23-25], but these were not observed in our cases. Therefore, our cases are not likely to be associated with SMZL transformation.

Therefore, these four patients (nos. 1-4) were diagnosed with de novo CD5-positive DLBCL [26]. Two of these patients with complex chromosomal aberration had chromosome abnormalities involving 3q27 (no. 2) and 11q13 (no. 4), which have been previously reported in CD5positive DLBCL [27]. Yamagichi et al. [28] recently reported four morphological variants of de novo CD5positive DLBCL. Using the molecular classification system by Hans et al. [29], lymphoma cells of $82 \%$ of the patients were of the non-germinal center B-cell type and the others were germinal center B-cell type. Interestingly, intravascular and/or intrasinusoidal lymphomatous infiltration was observed in $38 \%$ of the cells. Although data were not shown, the bone marrow, liver, and spleen were reported to be the most frequently involved anatomical sites. De novo CD5-positive DLBCL is heterogeneous in morphological, molecular, and clinical aspects. A potion of the cases with de novo CD5-positive DLBCL with splenomegaly may be DLBCLRP. While lymphoma cells of two other patients (nos. 5 and 6) in this study were CD5 negative, clinicopathological features other than CD5 were identical in these six patients (Table 7).

This high rate of CD5-positive lymphoma cells may be an aberrant expression of the aggressive lymphoma cells [30-32]. In previous genetic studies, it was suggested that de novo CD5-positive DLBCL originates from somatically mutated CD5 progenitor B cells [33, 34]. The mechanism of expression of CD5 in this lymphoma remains unsolved.

The lymphoma cells positive for CD10 in two patients (nos. 3 and 6) were considered germinal center B-cell type. Of the remaining four patients that were negative for CD10, three were negative for bcl-6 (nos. 1, 4, and 5) and one was positive for bcl-6 and MUM1 (no. 2). Therefore, later these were considered non-germinal center B-cell type (Table 3) [29]. Clinicopathological features were not clearly distinguishable among patients with germinal center B-cell-like DLBCL and those with non-germinal center B-cell-type DLBCL, except for the appearance of the lymphoma cells in the peripheral blood. However, our limited sample size makes it difficult to regard this feature as significant.

Table 4 Chromosomal analysis of DLBCLRP

\begin{tabular}{|c|c|c|}
\hline $\begin{array}{c}\text { Patient } \\
1\end{array}$ & 47, XY, der(1)del(1)(p?)dup(1)(q25q32), add(6)(q21), der(9)add(9)(p13)add(9)(q34), add(10)(q26), $+16,-19,+\mathrm{r}$ & $20 / 20$ \\
\hline \multirow[t]{2}{*}{$\begin{array}{l}\text { Patient } \\
2\end{array}$} & $\begin{array}{l}\text { 44, XY, t(3;14)(q27;q32),-4, add(5)(p11),-9, -10, add(12)(p13),-13,-15, add(18)(p11), add(21)(p11), +der(?)t(?;13)(?;q12), } \\
\operatorname{der}(?) \mathrm{t}(? ; 15)(? ; \mathrm{q} 11) ;+\operatorname{mar}\end{array}$ & $5 / 20$ \\
\hline & ( & $15 / 20$ \\
\hline $\begin{array}{l}\text { Patient } \\
3\end{array}$ & $48, \mathrm{X},-\mathrm{Y}, \operatorname{add}(2)(\mathrm{p} 23), \operatorname{del}(6)(\mathrm{q} ?),+\operatorname{add}(7)(\mathrm{q} 11), \operatorname{add}(7)(\mathrm{q} 22) \mathrm{x} 2,+11,+\operatorname{add}(18)(\mathrm{q} 21)$ & $20 / 20$ \\
\hline $\begin{array}{l}\text { Patient } \\
4\end{array}$ & 46, X, -Y, der(2)add(2)(p13)t(2;11)(q37;q13), $\operatorname{add}(4)(\mathrm{q} 35), \operatorname{del}(6)(\mathrm{q} ?), \operatorname{add}(8)(\mathrm{p} 11), \operatorname{add}(11)(\mathrm{q} 13),+18$ & $4 / 4$ \\
\hline $\begin{array}{l}\text { Patient } \\
5\end{array}$ & $46, \mathrm{XX}$ & $20 / 20$ \\
\hline $\begin{array}{l}\text { Patient } \\
6\end{array}$ & $46, X Y, \operatorname{inv}(9)(p 12 q 13)$ & $20 / 20$ \\
\hline
\end{tabular}


Table 5 Summary of the clinical findings DLBCLRP including our cases [4-13]

$\begin{array}{ll}\text { Age distribution (years) } & 40-81 \text { (median 64.5) } \\ \text { Male/female } & 18: 6 \\ \text { B symptom } & 14 / 15(93 \%) \\ \text { Weight of the spleen (g) (19 cases) } & 220-2,600 \\ & (\text { median } 1,300) \\ \text { Appearance of tumor cells in peripheral blood } & 10 / 23(43 \%) \\ \text { Bone marrow involvement } & 13 / 20(65 \%) \\ \text { Liver involvement } & 11 / 17(65 \%) \\ \text { Lymph node involvement } & \\ \text { Splenic hilus } & 5 / 16(31 \%) \\ \text { Abdominal } & 6 / 21(29 \%) \\ \text { Other } & 4 / 21(19 \%) \\ \text { Systemic lymph node involvement } & 0 / 21(0 \%)\end{array}$

DLBCLRP is a clinically highly aggressive lymphoma compared with conventional CD5-negative DLBCL and de novo CD5-positive DLBCL. The patients with de novo CD5positive DLBCL showed more aggressive clinical features and parameters (LDH level, clinical stage, and international prognostic index (IPI) score) than those with CD5-negative DLBCL [26]. All six patients in this study had fever, high LDH levels, clinical stage 4B, and a high-risk IPI score.

Another characteristic feature of DLBCLRP is hemophagocytosis of normal histiocytes observed in all the BMs (intensive cases; $1 / 5,20 \%$ ) and spleens (intensive cases; $2 / 6$, $33 \%$ ). This might be due to the high cytokine concentrations produced by these aggressive lymphoma cells [35]. But none fulfilled the criteria for adult hemophagocytic syndrome [36-38]. Moreover, the frequent presence of B symptoms $(14 / 15)$ was a characteristic of DLBCLRP. On the basis of

Table 6 Summary of pathological and phenotypic findings [4-13]

\begin{tabular}{lr}
\hline Pattern of splenic infiltration & \\
Splenic sinus & $14 / 19(74 \%)$ \\
Splenic cord & $23 / 24(96 \%)$ \\
Pattern of liver infiltration & \\
Intrasinusoidal & $8 / 8(100 \%)$ \\
Portal area & $7 / 8(88 \%)$ \\
Pattern of bone marrow infiltration & \\
Intrasinusoidal & $3 / 7(43 \%)$ \\
Interstitial & $10 / 11(91 \%)$ \\
Hemophagocytosis in spleen & $11 / 12(92 \%)$ \\
Hemophagocytosis in bone marrow & $4 / 5(80 \%)$ \\
Extramedullary hematopoiesis & $7 / 10(70 \%)$ \\
in spleen & \\
Tumor cell phenotype & \\
B-cell marker 24/24 & $24 / 24(100 \%)$ \\
CD5 (FCM) & $8 / 10(80 \%)$ \\
CD5 (IHC) & $3 / 12(25 \%)$ \\
CD10 (IHC) & $4 / 14(29 \%)$ \\
\hline
\end{tabular}

Table 7 Clinicopathological characteristics of DLBCLRP

Lymphoma cells infiltrate diffusely and non-cohesively in the cords of splenic red pulp

Lymphoma cells frequently involve the bone marrow and the liver at presentation

Lymph node involvement is rare and limited to the local area, and lymph node swelling is not significant. Systemic lymph node swelling is not observed even in the terminal phase of the disease. Intrasinusoidal as well as interstitial lymphomatous infiltration is observed in involved tissues

Lymphoma cells are often found in the peripheral blood Lymphoma cells frequently express surface CD5 antigen Hemophagocytosis of normal histiocytes is observed in the bone marrow and the splenic red pulp

these clinicopathological features, we propose that DLBCLRP is a distinct clinicopathological entity.

The clinicopathological features of the cases of the Asian variant of IVL (AIVL) with splenomegaly are similar to those of DLBCLRP. Splenectomy samples from two patients with AIVL had cut surfaces that were beef red in color and there was a diffuse, large, B-cell lymphoma cell infiltrate in the red pulp [14]. However, the international consensus meeting of intravascular large B-cell lymphoma (IVLBCL) proposed a new definition of IVLBCL, which included cases from both western and Asian countries [39]. They added the criterion of a concomitant minimal extravascular location of the neoplastic cells [40] to the WHO criteria, which states that the neoplastic lymphocytes might only be present in the lumina of the small vessels, such as capillaries [41]. DLBCLRP produced interstitial infiltration as well as intrasinusoidal lymphomatous infiltration in the BM, liver, and LN (Fig. 2d and Table 5). The infiltration of DLBCLRP lymphoma cells into the liver and $\mathrm{BM}$ was a more characteristic feature of the SMZL than AIVL. However, further studies are required to clarify these relationships.

Briefly, DLBCLRP is an aggressive lymphoma with B symptoms. During the early phase, it spreads to the liver and/or BM via intrasinusoidal and/or interstitial infiltration. Because our characterization of DLBCLRP was based on the observations of a limited number of patients, further studies are required to confirm that DLBCLRP is a distinct clinicopathologic entity.

Conflict of interest statement The authors declare no competing financial interests.

Open Access This article is distributed under the terms of the Creative Commons Attribution Noncommercial License which permits any noncommercial use, distribution, and reproduction in any medium, provided the original author(s) and source are credited. 


\section{References}

1. Mann RB (1999) Are there site-specific differences among extranodal aggressive B-cell neoplasms? Am J Clin Pathol 111:S144-S150

2. Harris NL, Aisenberg AC, Meyer JE et al (1984) Diffuse large cell (histiocytic) lymphoma of the spleen. Clinical and pathologic characteristics of ten cases. Cancer 54:2460-2467

3. Burke JS (1981) Surgical pathology of the spleen: an approach to the differential diagnosis of splenic lymphomas and leukemias. Part II. Diseases of the red pulp. Am J Surg Pathol 5:681-694

4. Kuratsune H, Machii T, Aozasa K et al (1988) B cell lymphoma showing clinicopathological features of malignant histiocytosis. Acta Haematol 79:94-98

5. Betman HF, Vardiman JW, Lau J (1994) T-cell-rich B-cell lymphoma of the spleen. Am J Surg Pathol 18:323-324

6. Faravelli A, Gambini S, Perego D et al (1995) Splenic lymphoma: unusual case with exclusive red pulp involvement. Pathologica 87:692-695

7. Kobrich U, Falk S, Karhoff M et al (1992) Primary large cell lymphoma of the splenic sinuses: a variant of angiotrophic B-cell lymphoma (neoplatic angioendotheliomatosis)? Hum Pathol 2:1184-1187

8. Kroft SH, Howard MS, Picker LJ et al (2000) De novo CD5+ diffuse large B-cell lymphomas. A heterogeneous group containing an unusual form of splenic lymphoma. Am J Clin Pathol 114:523-533

9. Mollejo M, Algara P, Mateo MS et al (2003) Large B-cell lymphoma presenting in the spleen: identification of different clinicopathologic conditions. Am J Surg Pathol 27:895-902

10. Morice WG, Rodriguez FJ, Hoyer JD et al (2005) Diffuse large Bcell lymphoma with distinctive patterns of splenic and bone marrow involvement: clinicopathologic features of two cases. Mod Pathol 18:495-502

11. Palutke M, Eisenberg L, Narang S et al (1988) B lymphocytic lymphoma (large cell) of possible splenic marginal zone origin presenting with prominent splenomegaly and unusual cordal red pulp distribution. Cancer 62:593-600

12. Salgado C, Feliu E, Montserrat E et al (1993) B-type large-cell primary splenic lymphoma with massive involvement of the red pulp. Acta Haematol 89:46-49

13. Stroup RM, Burke JS, Sheibani K et al (1992) Splenic involvement by aggressive malignant lymphomas of B-cell and T-cell types. A morphologic and immunophenotypic study. Cancer 69:413-420

14. Murase T, Nakamura S, Tashiro K et al (1997) Malignant histiocytosis-like B-cell lymphoma, a distinct pathologic variant of intravascular lymphomatosis: a report of five cases and review of the literature. Br J Haematol 99:656-664

15. Hashimoto K, Miura I, Chyubachi A et al (1995) Correlations of chromosome abnormalities with histologic and immunologic characteristics in 49 patients from Akita, Japan with non-Hodgkin lymphoma. Cancer Genet Cytogenet 81:56-65

16. Mitelman F (ed) ISCN (1995). An international system for human cytogenetic nomenclature. Karger, Basel

17. Berger F, Felman P, Thieblemont $C$ et al (2000) Non-MALT marginal zone B-cell lymphomas: a description of clinical presentation and outcome in 124 patients. Blood 95:1950-1956

18. Camacho FI, Mollejo M, Mateo MS et al (2001) Progression to large B-cell lymphoma in splenic marginal zone lymphoma: a description of a series of 12 cases. Am J Surg Pathol 25:1268-1276

19. Mollejo M, Menárguez J, Lloret E, Sánchez A, Campo E, Algara P, Cristóbal E, Sánchez E, Piris MA (1995) Splenic marginal zone lymphoma: a distinctive type of low-grade B-cell lymphoma. A clinicopathological study of 13 cases. Am J Surg Pathol 19:1146-1157

20. Van Huyen JP, Molina T, Delmer A et al (2000) Splenic marginal zone lymphoma with or without plasmacytic differentiation. Am J Surg Pathol 24:1581-1592
21. Dierlamm J, Michaux L, Wlodarska I et al (1996) Trisomy 3 in marginal zone B-cell lymphoma: a study based on cytogenetic analysis and fluorescence in situ hybridization. Br J Haematol 93:242-249

22. Mateo M, Mollejo M, Villuendas R et al (1999) 7q31-32 allelic loss is a frequent finding in splenic marginal zone lymphoma. Am J Pathol 154:1583-1589

23. Chacón JI, Mollejo M, Muñoz E et al (2002) Splenic marginal zone lymphoma: clinical characteristics and prognostic factors in a series of 60 patients. Blood 100:1648-1654

24. Franco V, Florena AM, Iannitto E (2003) Splenic marginal zone lymphoma. Blood 101:2464-2472

25. Iannitto E, Ambrosetti A, Ammatuna E et al (2004) Splenic marginal zone lymphoma with or without villous lymphocytes. Hematologic findings and outcomes in a series of 57 patients. Cancer 101:2050-2057

26. Yamaguchi M, Seto M, Okamoto M et al (2002) De novo CD5+ diffuse large B-cell lymphoma: a clinicopathologic study of 109 patients. Blood 99:815-821

27. Yoshioka T, Miura I, Kume M et al (2005) Cytogenetic features of de novo CD5-positive diffuse large B-cell lymphoma: chromosome aberrations affecting 8p21 and 11q13 constitute major subgroups with different overall survival. Genes Chromosomes Cancer 42:149-157

28. Yamaguchi M, Nakamura N, Suzuki R et al (2008) De novo CD5+ diffuse large B-cell lymphoma: results of a detailed clinicopathological review in 120 patients. Haematologica 93(8):1195-1202

29. Hans CP, Weisenburger DD, Greiner TC et al (2004) Confirmation of the molecular classification of diffuse large B-cell lymphoma by immunohistochemistry using a tissue microarray. Blood 103:275-282

30. Ballesteros E, Osborne BM, Matsushima AY (1998) CD5+ lowgrade marginal zone B-cell lymphomas with localized presentation. Am J Surg Pathol 22:201-207

31. Ferry JA, Yang WI, Zukerberg LR et al (1996) CD5+ extranodal marginal zone B-cell (MALT) lymphoma. A low grade neoplasm with a propensity for bone marrow involvement and relapse.. Am J Clin Pathol 105:31-37

32. Tiesinga JJ, Wu CD, Inghirami C (2000) CD5+ follicle center lymphoma. immunophenotyping detects a unique subset of "floral" follicular lymphoma. Am J Clin Pathol 114:912-921

33. Katzenberger T, Lohr A, Schwarz S et al (2003) Genetic analysis of de novo CD5+ diffuse large B-cell lymphomas suggests an origin from a somatically mutated CD5+ progenitor B cell. Blood 101:699-702

34. Nakamura N, Hashimoto Y, Kuze T et al (1999) Analysis of the immunoglobulin heavy chain gene variable region of CD5positive diffuse large B-cell lymphoma. Lab Invest 79:925-933

35. Imashuku S (1997) Differential diagnosis of hemophagocytic syndrome: underlying disorders and selection of the most effective treatment. Int J Hematol 66:135-151

36. Tsuda $H$ (1997) Hemophagocytic syndrome in children and adults. Int J Hematol 65:215-226

37. Wong KF, Chan JK (1992) Reactive hemophagocytic syndromea clinicopathologic study of 40 patients in an Oriental population. Am J Med 93:177-180

38. Yao M, Cheng AL, Su IJ et al (1994) Clinicopathological spectrum of hemophagocytic syndrome in Epstein-Barr virus associated peripheral T-cell lymphoma. Br J Haematol 87:535-543

39. Ponzoni M, Ferreri AJ, Campo E et al (2007) Definition, diagnosis, and management of intravascular large B-cell lymphoma: proposals and perspectives from an international consensus meeting. J Clin Oncol 25:3168-3173

40. Ponzoni M, Arrigoni G, Gould VE et al (2000) Lack of CD 29 (beta1 integrin) and CD 54 (ICAM-1) adhesion molecules in intravascular lymphomatosis. Hum Pathol 31:220-226

41. Gatter KC, Warnke RA (2001) Intravascular large B-cell lymphoma. In: Jaffe ES, Harris NL, Stein H, Vardiman JW (eds) Tumors of haematopoietic and lymphoid tissues. IARC, Lyon 